\title{
Effect of lowered pH on marine phytoplankton growth rates
}

\author{
Terje Berge ${ }^{1, *}$, Niels Daugbjerg ${ }^{1}$, Bettina Balling Andersen ${ }^{2}$, Per Juel Hansen ${ }^{2}$ \\ ${ }^{1}$ Section for Evolution and Ecology of Aquatic Organisms. Department of Biology, University of Copenhagen, \\ Øster Farimagsgade 2d, 1353 Copenhagen K, Denmark \\ ${ }^{2}$ Section of Marine Biology, Department of Biology, University of Copenhagen, Strandpromenaden 5, 3000 Helsingør, \\ Denmark
}

\begin{abstract}
Continued anthropogenic carbon emissions are expected to result in an increase in atmospheric $\mathrm{CO}_{2}$ concentration to $700 \mathrm{ppm}$ by the end of this century. This will cause a corresponding drop in the global average surface water $\mathrm{pH}$ of the oceans by $\sim 0.4$ units to $\sim 7.8$ and an increase in the $\mathrm{CO}_{2} \mathrm{Con}_{-}$ centration of seawater. Ocean acidification may potentially both stimulate and reduce primary production by marine phytoplankton. Data are scarce on the response of marine phytoplankton growth rates to lowered $\mathrm{pH} /$ increased $\mathrm{CO}_{2}$. Using the acid addition method to lower the seawater $\mathrm{pH}$ and manipulate the carbonate system, we determined in detail the lower $\mathrm{pH}$ limit for growth rates of 2 model species of common marine phytoplankton. We also tested whether growth and production rates of 6 other common species of phytoplankton were affected by ocean acidification (lowered to $\mathrm{pH}$ 7.0). The lower $\mathrm{pH}$ limits for growth of the dinoflagellate Heterocapsa triquetra and the cryptophyte Teleaulax amphioxeia were $\mathrm{pH} \sim 6.0$ and 6.3 , respectively. The growth rates of these 2 species were significantly reduced in the range of $\mathrm{pH} 6.4$ to 6.5. Cell volume, growth, and production rates of the 6 other phytoplankton species were statistically similar in the $\mathrm{pH}$ range of $\sim 7.0$ to 8.5. Our results and literature reports on growth at lowered $\mathrm{pH}$ indicate that marine phytoplankton in general are resistant to climate change in terms of ocean acidification, and do not increase or decrease their growth rates according to ecological relevant ranges of $\mathrm{pH}$ and free $\mathrm{CO}_{2}$. We speculate about whether common natural $\mathrm{pH}$ fluctuations in time and space from 7.0 to 9.0 make phytoplankton capable of tolerating near-future ocean acidification. However, due to the less fluctuating $\mathrm{pH}$ environment of oceanic regions compared to coastal regions, truly oceanic species may be more sensitive to lowered $\mathrm{pH}$ than coastal species.
\end{abstract}

KEY WORDS: Marine phytoplankton $\cdot$ Lowered pH $\cdot$ Growth rates $\cdot$ Primary production $\cdot$ Ocean acidification

Resale or republication not permitted without written consent of the publisher

\section{INTRODUCTION}

By the end of the present century, burning of fossil fuels will have doubled atmospheric $\mathrm{CO}_{2}$ concentration and increased the total inorganic carbon $\left(\mathrm{TCO}_{2}\right)$ content of the surface ocean by $\sim 12 \%$ compared to preindustrial levels (Houghton et al. 2001). The associated drop in the average surface water $\mathrm{pH}$ from $\sim 8.2$ to $\sim 7.8$ represents one of the most rapid ocean acidification events on earth over the past 300 Myr (Caldeira \& Wickett 2003). Equilibrium pools of $\mathrm{TCO}_{2}$ species (i.e. free $\mathrm{CO}_{2}, \mathrm{HCO}_{3}{ }^{-}$, and $\mathrm{CO}_{3}{ }^{2-}$ ) will change, and in- creased free $\mathrm{CO}_{2}$ could potentially enhance phytoplankton primary production (Riebesell et al. 2007). This is because free $\mathrm{CO}_{2}$ concentrations in the oceans are presently at limiting levels for RUBISCO, the enzyme responsible for the first step in photosynthesis (Beardall \& Raven 2004). However, most phytoplankton species possess $\mathrm{CO}_{2}$ concentrating mechanisms (CCMs), which increase free $\mathrm{CO}_{2}$ in the vicinity of RUBISCO and saturate photosynthesis in the present ocean (Giordano et al. 2005). On the other hand, a pH drop of $\sim 0.4$ units, as predicted, represents a $\sim 150 \%$ increase in the $\mathrm{H}^{+}$concentrations, which may affect 
intracellular $\mathrm{pH}$, membrane potential, energy partitioning, and enzyme activity (Beardall \& Raven 2004, Riebesell 2004, Giordano et al. 2005). Thus, ocean acidification may reduce phytoplankton growth rates through direct $\mathrm{pH}$ effects.

Experimental data on the effects of lowered $\mathrm{pH}$ and increased free $\mathrm{CO}_{2}$ on growth and productivity of phytoplankton are few and do not show a clear pattern (Iglesias-Rodriguez et al. 2008, Langer et al. 2009). Some studies dealing with natural plankton communities, using micro- and mesocosms, have shown altered species composition in response to lowered $\mathrm{pH}$ and increased free $\mathrm{CO}_{2}$, while other studies have shown very limited effects on species composition and community production (Tortell et al. 2002, Kim et al. 2006, Feng et al. 2009, Nielsen et al. in press). While microand mesocosm studies have the advantage of allowing the analyses of complete, natural phytoplankton communities, the conclusions from such studies are difficult to interpret, and experimental artifacts may be common. (1) Since plankton communities are not subjected to sedimentation in closed experimental bottles, as they are in nature, a few fast-growing species (i.e. non-motile diatoms) tend to dominate such communities within 1 wk of incubation, making a proper community description difficult. (2) Dilution (typically $50 \%$ $\mathrm{d}^{-1}$ ) is often applied to the incubation bottles to avoid nutrient limitation and increased $\mathrm{pH}$ during the experiment. This further contributes to the problem of using mesocosm incubations because slow-growing rare species are removed. (3) Observed apparent effects of lowered $\mathrm{pH}$ and increased free $\mathrm{CO}_{2}$ on phytoplankton may be indirect rather than direct, if grazers and competitors are affected (i.e. heterotrophic protists; Pedersen \& Hansen 2003). (4) Tests of the required acclimation period of natural communities are impossible, and a long acclimation period will change the system compared to the community that was originally sampled. Thus, due to the problems with mesocosm studies, there is a need for controlled laboratory experiments to determine the isolated effects of lowered $\mathrm{pH}$ and increased free $\mathrm{CO}_{2}$ on common marine phytoplankton species and strains.

Despite the increasing scientific and public awareness of the potential effects of ocean acidification, relatively few laboratory studies have focused on effects of lowered $\mathrm{pH}$ and increased free $\mathrm{CO}_{2}$ on marine phytoplankton monocultures. So far no or very limited effects of low $\mathrm{pH}$ on diatoms, prymnesiophytes, and dinoflagellates have been found (Burkhardt et al. 1999, 2001, Rost et al. 2003). However, some focus has been on calcifying phytoplankton organisms (mainly the ecologically important coccolithophorids), because these are expected to be particularly vulnerable (Riebesell 2004). This is due to the fact that the satura- tion state of the oceans with respect to calcite and aragonite will decrease with decreasing concentrations of $\mathrm{CO}_{3}{ }^{2-}$ (Riebesell et al. 2000). However, for strains of the well-studied coccolithophorid Emiliania huxleyi, unaffected, decreased, or increased calcification rates and photosynthesis have been found in lowered $\mathrm{pH}$ and increased free $\mathrm{CO}_{2}$ (Riebesell et al. 2000, Iglesias-Rodriguez et al. 2008, Langer et al. 2009). Overall, the few laboratory experiments on marine phytoplankton species - in general subjected to lowered $\mathrm{pH}$ and increased free $\mathrm{CO}_{2}$ - have indicated that maximum growth rates can be maintained at $\mathrm{pH} 7.8$ and even as far down as pH 7.0 (Swift \& Taylor 1966, Chen \& Durbin 1994, Taraldsvik \& Myklestad 2000).

Two main approaches have been used to manipulate $\mathrm{pH}$ and the carbonate system in studies involving phytoplankton and responses to lowered $\mathrm{pH}$ and increased free $\mathrm{CO}_{2}$. These are based on $\mathrm{CO}_{2}$ bubbling or acid/base additions (Hurd et al. 2009). Heated discussions on which technique is most suitable have resulted in several recent papers considering different effects of the 2 methods (Hurd et al. 2009, Schulz et al. 2009, Shi et al. 2009). The main difference lies in their different effects on the carbonate speciation, the total pool of inorganic carbon $\left(\mathrm{TCO}_{2}\right)$, and alkalinity of seawater medium. $\mathrm{CO}_{2}$ bubbling leads to an increase in $\mathrm{TCO}_{2}$ while alkalinity is kept constant and $\mathrm{pH}$ decreases. This reflects the changes related to ocean acidification due to increased atmospheric $\mathrm{CO}_{2}$. In the $\mathrm{HCl}$ addition method, $\mathrm{TCO}_{2}$ is kept stable while total alkalinity and pH decrease. Nevertheless, there is emerging recognition that the use of the 2 techniques depends on the questions being asked (Hurd et al. 2009, Schulz et al. 2009, Shi et al. 2009). For example, when investigations focus on phytoplankton calcification, the calcite and aragonite saturation states depend on the alkalinity and the $\mathrm{CO}_{3}{ }^{2-}$ concentration. A problem with $\mathrm{CO}_{2}$ bubbling is that growth of several species, especially dinoflagellates, is negatively affected by the stress introduced by the bubbles. On the other hand for non-calcifying species, saturation states are of no concern, while growth limitation by $\mathrm{TCO}_{2}$ could be a potential problem. However, several studies have shown that most phytoplankton species possess CCMs and are only limited by $\mathrm{TCO}_{2}$ at very low concentration (Hansen et al. 2007, Hurd et al. 2009). The difference in $\mathrm{TCO}_{2}$ between the acid-addition and $\mathrm{CO}_{2}$-bubbling represents only a small difference in $\mathrm{HCO}_{3}{ }^{-}$concentration (Brewer 1997), which should not affect photosynthesis and growth (Hurd et al. 2009). Measuring growth rates of 2 diatom species at lowered $\mathrm{pH}$, Chen \& Durbin (1994) tested both methods and reported no differences.

Here we focused on the effects of lowered $\mathrm{pH}$ (by $\mathrm{HCl}$ addition) on the growth rates of 8 common species of phytoplankton representing all major marine 
classes. The study addressed 3 main questions: (1) Are common phytoplankton species sensitive to $\mathrm{pH}$ in the range that can be expected by the end of this century $(\sim 7.8)$ ? (2) How low is the lower $\mathrm{pH}$ limit for growth of selected model coastal phytoplankton species? (3) Does the acclimation period in $\mathrm{pH}$ manipulation studies affect growth and production rates?

\section{MATERIALS AND METHODS}

Phytoplankton cultures. The 8 phytoplankton species included in this study (Table 1) originated either from the Scandinavian Culture Collection of Algae \& Protozoa (SCCAP, www.sccap.dk) or were established from water samples $(60 \mathrm{ml})$ collected from land in coastal harbors in Denmark and Norway during 2007 and 2008 (5 strains). Preferably, newly isolated strains were used, due to potential artefacts by laboratory maintenance (Hurd et al. 2009, Lakeman et al. 2009). Our choice of species was based on an attempt to include the most common coastal marine phytoplankton groups (diatoms, dinoflagellates, prymnesiophytes, and cryptophytes), and to cover a large size range of organisms (Table 1).

Isolation of single cells was done with the use of a drawn-out Pasteur pipette, and the cells were washed by transferring them through 3 drops of fresh medium (L1) using an Olympus CKX-40 inverted microscope with a $20 \times$ objective. Depending on species, successful culture establishment was achieved from 10 to $70 \%$ of the isolated cells. The used strains were deposited in SCCAP (Table 1), if not otherwise stated. All strains were maintained in $\mathrm{F} / 2$ medium at a salinity of 30 and a temperature of $15^{\circ} \mathrm{C}$, under a light intensity of 20 to $50 \mu \mathrm{mol}$ photons $\mathrm{m}^{-2} \mathrm{~s}^{-1}$ in a light:dark cycle of 14:10 h.
Experiments and conditions. In Expt 1, the goal was to determine at what level of lowered $\mathrm{pH}$ the growth rates of 2 common species of phytoplankton, viz. the dinoflagellate Heterocapsa triquetra and the cryptophyte Teleaulax amphioxeia, were affected compared to growth rates at natural levels ( $\mathrm{pH} \sim 8.1$ to 8.5 ). Moreover we wanted to determine the lower $\mathrm{pH}$ tolerance for positive growth rates. Two to $3 \mathrm{wk}$ before setting up the experiment, the stock cultures were introduced and acclimated to a higher experimental light intensity of $150 \mu \mathrm{mol}$ photons $\mathrm{m}^{-2} \mathrm{~s}^{-1}$, than the light conditions in which they were maintained (see above). The acclimatization to light conditions was carried out by keeping the $\mathrm{pH}$ at $\sim 8$ by diluting with fresh medium of $\mathrm{pH} 7.9$ every 3 to $4 \mathrm{~d}$, and cell concentrations were kept at $<5000$ cells ml $^{-1}$ to maintain balanced exponential growth. Experimental salinity was 30 and temperature was $15^{\circ} \mathrm{C}$ (similar to culture maintenance). Light was measured with a spherical sensor (Li185B, Li-Cor) and provided in a light:dark cycle of 14:10 h. All treatments were run in closed sterile polycarbonate bottles $(270 \mathrm{ml})$ that were filled to capacity to avoid gas exchange with the air. All treatments were run in triplicate. To create a homogenous light field, the experimental bottles were illuminated from below and positions changed randomly during sampling every day.

During the last 1 to $4 \mathrm{~d}$ of acclimation to light intensity, $\mathrm{pH}$ was adjusted stepwise, by $0.5 \mathrm{pH}$ units $12 \mathrm{~h}^{-1}$, until the culture medium had reached the $\mathrm{pH}$ of the specific treatment. The $\mathrm{pH}$ in the fresh medium was adjusted by adding 0.1 to 1.0 molar $\mathrm{HCl}$ and $\mathrm{NaOH}$. The $\mathrm{pH}$ was measured to the nearest 0.01 unit with a pH meter (Copenhagen pHM-83 Autocal). The pH sensor was calibrated on a daily basis using IUPAC buffers $\mathrm{pH} 7.0$ and 10.0. To keep a constant $\mathrm{pH}$ during the incubation period (up to $10 \mathrm{~d}$ ), low cell concentrations were used by diluting the cultures during sampling with fresh medium of desired $\mathrm{pH}$. Following $4 \mathrm{~d}$ of exponential growth in the triplicate bottles, samples for enumeration of cell concentrations were taken every day for 5 to $6 \mathrm{~d}$ (see Fig. 1), and the sample volume was replaced with fresh medium with a $\mathrm{pH}$ of the corresponding $\mathrm{pH}$ treatment. $\mathrm{pH}$ was measured both before and after sampling and dilution. Cell concentrations were measured manually by counting at least 300 Lugol's acid (1\% final concentration)-fixed cells in SedgewickRafter chambers. The dilution rate corresponded approximately to the growth rate (see Fig. 1), and sample volumes ranged from 10 to $60 \%$ of the 
total volume. From the obtained growth curves (cell concentration as a function of time), growth rates were estimated (see calculations).

The concentration of $\mathrm{TCO}_{2}$ was measured in triplicate in fresh medium and in the experimental bottles on the final day of the growth rate experiments (see Figs. 1 $\& 2$ ), over the range of treatments from $\mathrm{pH} 6.0$ to 8.6. Measurements were done using an infrared gas analyzer (IRGA) and a bicarbonate standard $\left(2 \mathrm{mmol} \mathrm{l}^{-1}\right)$, according to Hansen et al. (2007). From pH, salinity, temperature, and $\mathrm{TCO}_{2}$, we calculated the concentration of the carbon species in the medium (see below).

In Expt 2, we studied potential reduction of growth rates and cell size (cell volume; $\mu^{3}$ ) and calculated the production rates $\left(\mu \mathrm{m}^{3} \mathrm{~d}^{-1}\right)$ of 6 different species of coastal phytoplankton at naturally occurring levels of $\mathrm{pH}$ 7.5, 8.0, and 8.5. We also included 1 treatment of, for marine conditions, unusually low $\mathrm{pH}(\sim 7.0)$. The species selected were the dinoflagellates Karlodinium veneficum, Prorocentrum micans, and P. minimum; the diatom Coscinodiscus granii, the haptophyte Prymnesium parvum, and the cryptophyte Rhodomonas marina. All conditions were the same as in Expt 1, except that in Expt 2, at the lowest cell concentrations, including the large diatom C. granii $\left(310000 \mu^{3}\right)$ and the large dinoflagellate $P$. micans $\left(11000 \mu^{3}\right)$, all cells in $20 \mathrm{ml}$ of sample were settled in multidishes (24-well dishes) and counted, using an inverted microscope. In these treatments of lower cell concentrations, at least 100 cells were counted. The reason for using lower cell concentrations was due to the large size and therefore the higher influence of photosynthesis on the $\mathrm{pH}$ of the experimental medium. Moreover, in Expt 2, cell dimensions (length \& width) were measured manually on the first 20 Lugol-fixed cells encountered on micrographs taken at $250 \times$ magnification using an inverted microscope, and the measure-tool in Adobe Photoshop CS3. The cells in each $\mathrm{pH}$ treatment were grouped across the experimental period ( $>5 \mathrm{~d}$ ) by mixing equal cell numbers from each sampling occasion, before sedimentation for at least $12 \mathrm{~h}$ in sedimentation chambers. A high precision object-micrometer was used to convert pixels to $\mu \mathrm{m}$.

Calculations and statistics. Exponential growth rates in $\mu\left(\mathrm{d}^{-1}\right)$ were calculated as:

$$
\mu=\ln \left(X_{t_{2}}-X_{t_{1}}\right) / t_{2}-t_{1}
$$

where $X_{t_{2}}$ and $X_{t_{1}}$ is the cell concentration at the end $\left(t_{2}\right)$ and start $\left(t_{1}\right)$ of the sampled interval $(24 \mathrm{~h})$, respectively. Due to the daily dilutions during samplings, growth rates were averaged in each replicate bottle, over a period of 5 to $6 \mathrm{~d}$ of exponential growth (see
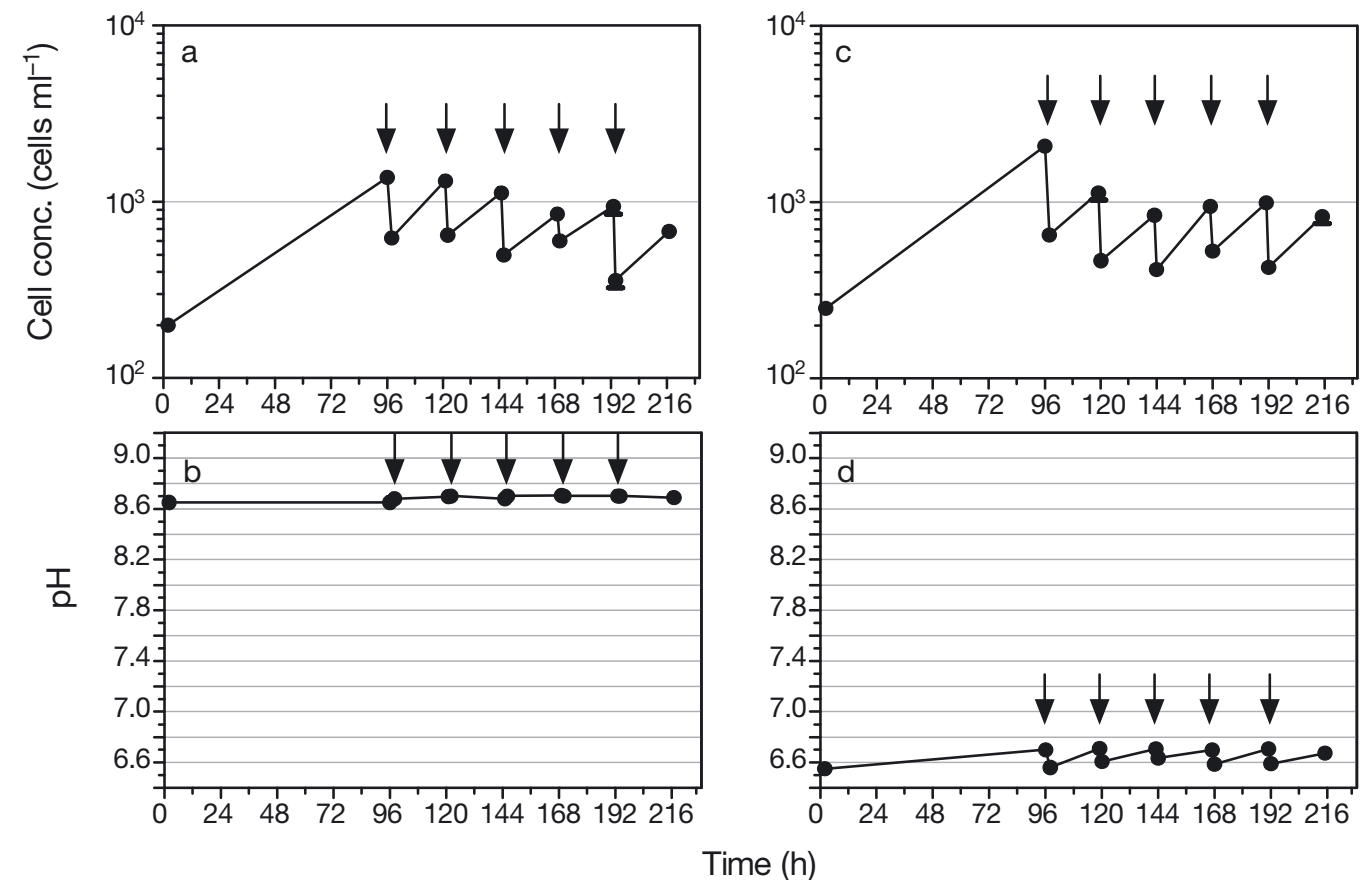

Fig. 1. Heterocapsa triquetra. Example of growth rate estimation from Expt 1 including a high and a low pH treatment. This same method was used in both Expt 1 and Expt 2. Cell concentration $(\mathrm{a}, \mathrm{c})$ and $\mathrm{pH}(\mathrm{b}, \mathrm{d})$ are shown as a function of time. The first $4 \mathrm{~d}$ $(96 \mathrm{~h})$ represented the acclimation period, while the subsequent $5 \mathrm{~d}$ were included in the estimation of acclimated balanced growth rates. Arrows indicate time of dilutions and sampling. Total inorganic carbon $\left(\mathrm{TCO}_{2}\right)$ was measured in the medium used for dilutions and at the final sampling point. The carbonate system at the different $\mathrm{pH}$ is presented in Fig. 2. Data points are means $\pm \mathrm{SE}(\mathrm{n}=3)$ 
Fig. 1). Only linear parts of semi-log plots of concentration as a function of time were included (see Figs. 3 \& 5). Concentrations of free $\mathrm{CO}_{2}, \mathrm{HCO}_{3}{ }^{-}$, and $\mathrm{CO}_{3}{ }^{2-}$ were calculated according to Plath et al. (1980) from measured $\mathrm{TCO}_{2}$ (see above), $\mathrm{pH}$, salinity, and temperature of the medium using the dissociation constants of Mehrbach et al. (1973). In Expt 2, cell size $\left(\mu m^{3}\right)$ was estimated by assuming simple geometric shapes, and was based on length and width measurements (see above). Under the assumption that potential effects of Lugol's fixation on cell size was similar within species at the ranges of $\mathrm{pH}$ used, net specific production rates $\left(\mu \mathrm{m}^{3} \mathrm{cell}^{-1} \mathrm{~d}^{-1}\right)$ were calculated as the product of exponential growth rate $\left(\mathrm{d}^{-1}\right)$ and specific cell size $\left(\mu \mathrm{m}^{3}\right)$ and compared. All statistical analyses were done using the free statistical software $\mathrm{R}$ and 1-factor analysis of variance (ANOVA), and Tukey's multiple comparisons test was used to test for differences in growth rates, production rates, and cell size between the $\mathrm{pH}$ treatments. A significance level of 0.05 was chosen.

\section{RESULTS}

\section{pH and the carbonate system}

At $\mathrm{pH}$ levels $>7.0$, we were able to keep $\mathrm{pH}$ constant during the incubation period (Fig. 1a,b) with only small changes in $\mathrm{pH}$ between samplings (change of $<0.05 \mathrm{pH}$ units). At $\mathrm{pH}<7.0$, the $\mathrm{pH}$ varied at most $0.2 \mathrm{pH}$ units (at $\mathrm{pH}$ 6.0) from the treatment $\mathrm{pH}$ between dilutions with fresh medium during sampling (Fig. 1c,d).

We measured the concentration of $\mathrm{TCO}_{2}$ and calculated the carbon speciation in our medium and in the experimental medium after incubations (Fig. 2). This was done at 4 different $\mathrm{pH}$ levels in fresh medium and in experimental medium at the end of the incubation period $(7-8 \mathrm{~d})$ at $9 \mathrm{pH}$ levels from Expt 1 . The $\mathrm{pH}$ range tested covered the range of $\mathrm{pH}$ and free $\mathrm{CO}_{2}$ used in all treatments in both experiments. $\mathrm{TCO}_{2}$ concentrations in the fresh medium varied from 0.7 to $1.9 \mathrm{mmol} \mathrm{l}^{-1}$ over the range of $\mathrm{pH}$ treatments tested (6.0 to 8.6; Fig. 2a). Calculated free $\mathrm{CO}_{2}$ in the fresh medium decreased as a function of $\mathrm{pH}$ and varied from 4 to $331 \mu \mathrm{mol} \mathrm{l}^{-1}$ (Fig. 2b) while $\mathrm{CO}_{3}{ }^{2-}$ increased as a function of $\mathrm{pH}$ (data not shown). In the medium sampled at the end of the incubation period, $\mathrm{TCO}_{2}$ was in the range of $\sim 0.8$ to $1.8 \mathrm{mmol} \mathrm{l}^{-1}$ and free $\mathrm{CO}_{2}$ ranged from 4 to $441 \mu \mathrm{mol} \mathrm{l}^{-1}$ over a range from $\mathrm{pH} 6.0$ to 8.6 (Fig. 2). Thus, the concentration of $\mathrm{TCO}_{2}$ and free $\mathrm{CO}_{2}$ did not decrease noticeably in our experimental bottles during the course of the growth rate experiments at different $\mathrm{pH}$ values. From $\mathrm{pH} \sim 7.0$ to 8.5 , which repre-
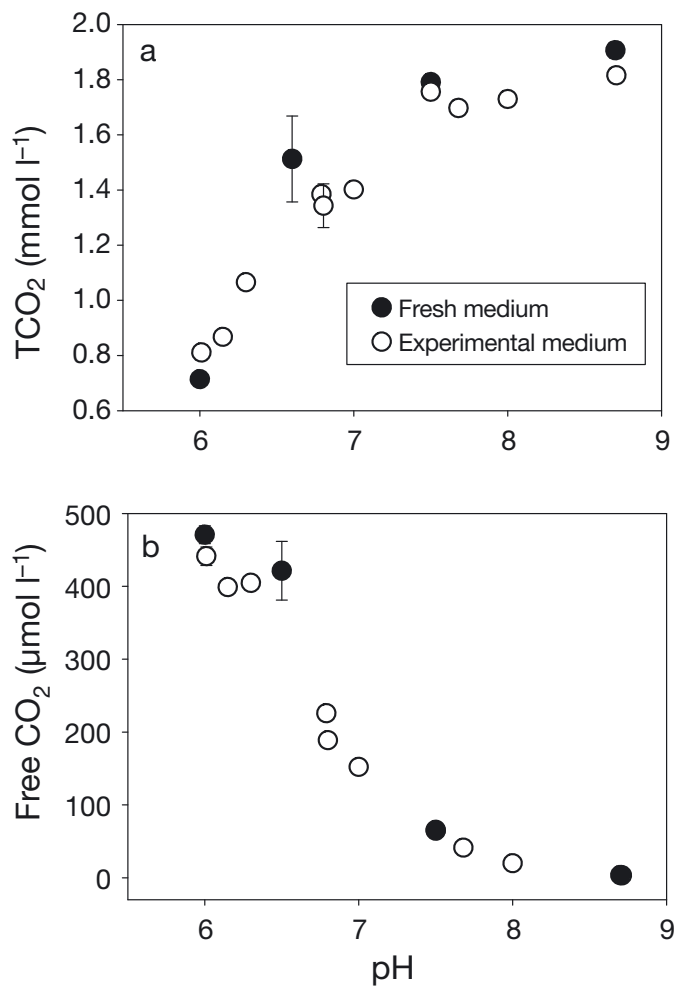

Fig. 2. Expt 1. Carbonate system manipulated with $\mathrm{HCl}$ additions. (a) Total inorganic carbon $\left(\mathrm{TCO}_{2}\right)$ and (b) free $\mathrm{CO}_{2}$ as a function of $\mathrm{pH}$ in the medium and in the medium at termination of the experiment after 7 to $8 \mathrm{~d}$. $\mathrm{pH}$ was measured using a 2-point calibration $\mathrm{pH}$ meter that was calibrated daily using IUPAC buffers of $\mathrm{pH} 7$ and $10 . \mathrm{TCO}_{2}$ was measured using an infrared gas analyzer (IRGA) compared with a $2.0 \mathrm{mM}$ bicarbonate standard solution. Estimations of $\mathrm{CO}_{2}$ were based on Plath et al. (1980) and Mehrbach et al. (1973). Data points are means $\pm \operatorname{SE}(n=3)$

sented the $\mathrm{pH}$ range used in Expt 2, $\mathrm{TCO}_{2}$ was kept relatively constant from $\sim 1.5$ to $1.8 \mathrm{mmol} \mathrm{l}^{-1}$, and free $\mathrm{CO}_{2}$ varied from $\sim 150$ to $5 \mu \mathrm{mol} \mathrm{l} \mathrm{l}^{-1}$.

\section{Growth rate as a function of lowered $\mathrm{pH}$ in two common species of phytoplankton}

In Expt 1, the concentration of cells increased exponentially as a function of time, and no lag phase was observed in any of the $\mathrm{pH}$ treatments for both species (Fig. 3). At pH 5.8, the growth rate of the dinoflagellate Heterocapsa triquetra was negative (Fig. 4a), but increased as a function of $\mathrm{pH}$ from $\mathrm{pH}$ 6.0. H. triquetra maintained a maximum growth rate of $\sim 0.9 \mathrm{~d}^{-1}$ in the range of pH 6.9 to 8.7 (Tukey's test, p > 0.05; Fig. 4a). Below a pH of 6.9, the growth rate of $H$. triquetra was reduced and was $0.7 \mathrm{~d}^{-1}$ at $\mathrm{pH} 6.7$, significantly different from the maximum growth rates (Tukey's test, $\mathrm{p}<$ 0.05; Fig. 4a). 


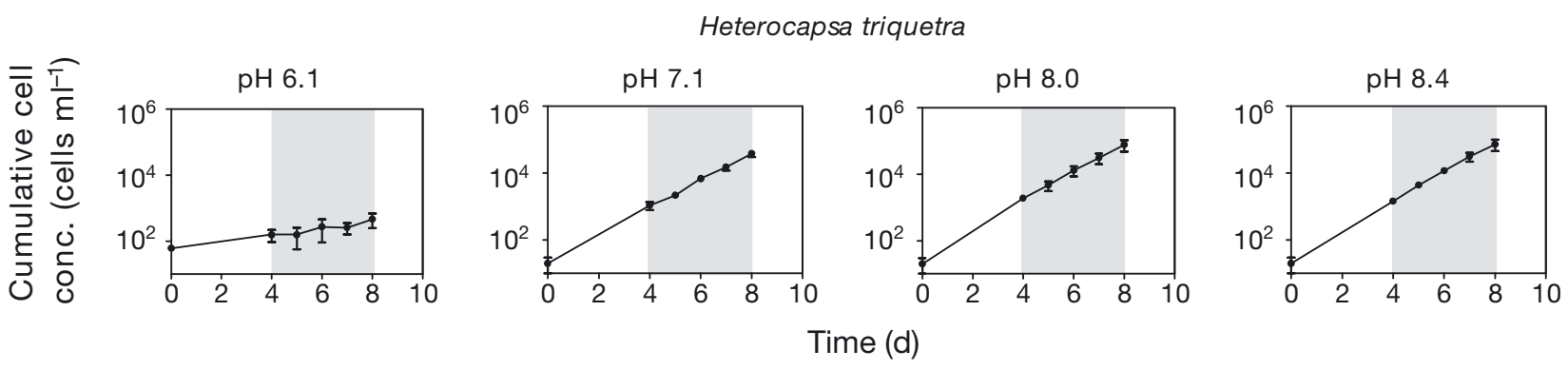

Fig. 3. Heterocapsa triquetra. Expt 1. Lower $\mathrm{pH}$ limit for growth. Cumulative cell concentrations as a function of time in 4 of the 11 treatments. Data points are means $\pm \mathrm{SE}(\mathrm{n}=3)$. Shaded areas represent data points included in estimations of balanced acclimated growth rates (Fig. 4). Data for Teleaulax amphioxeia not shown. No significant differences were observed between the growth rates in the acclimation period (time 0 to 4 ) and the acclimated growth rates ( $p>0.05$ )

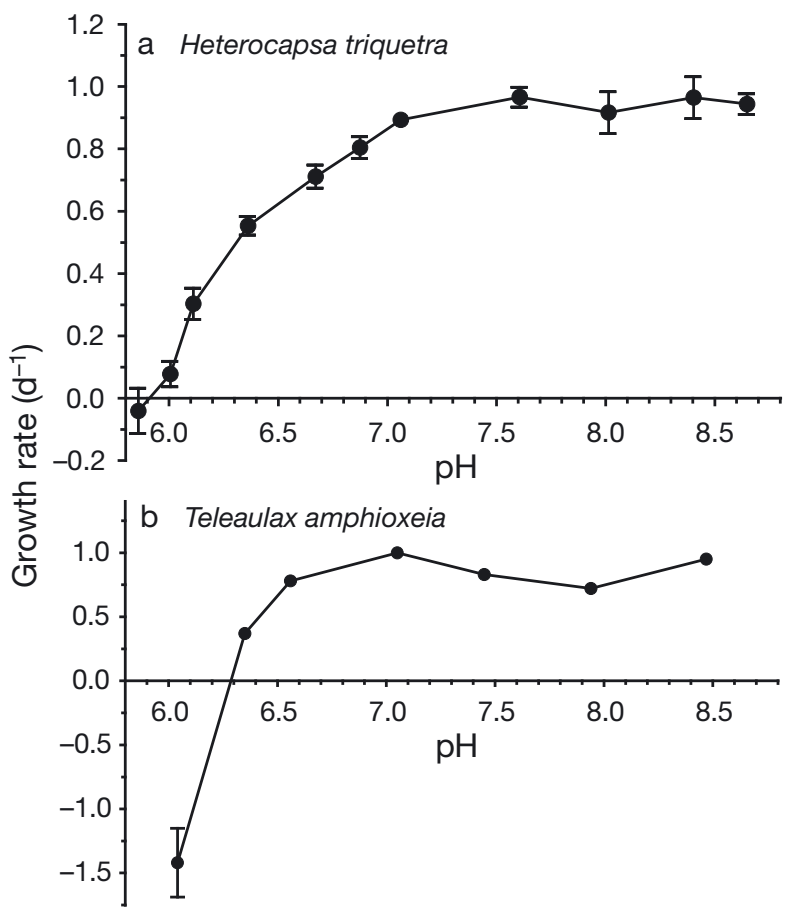

Fig. 4. Heterocapsa triquetra and Teleaulax amphioxeia. Expt 1. Lower pH limit for growth. Growth rate of (a) the dinoflagellate $H$. triquetra and (b) the cryptophyte $T$. amphioxeia as a function of lowered $\mathrm{pH}$. The cultures were grown under nutrient and light replete conditions and acclimation to $\mathrm{pH}$ during a period of $4 \mathrm{~d}$ where $\mathrm{pH}$ was kept constant. Growth rates were averaged over a period of $5 \mathrm{~d}$ and represented linear parts on semi-log growth curves as shown in Fig. 3. Growth rate of $H$. triquetra was constant and unaffected by $\mathrm{pH}$ levels $>6.6$, and half their maximum growth rate was achieved at $\mathrm{pH} \sim 6.3$. Growth rates of $T$. amphioxeia were unaffected in the $\mathrm{pH}$ range of 6.4 to 8.5. Data points are means $\pm \mathrm{SE}(\mathrm{n}=3)$

At $\mathrm{pH}$ 6.0, the growth rate of the cryptophyte Teleaulax amphioxeia was negative (Fig. 4b), but increased as a function of $\mathrm{pH}$ to a maximum level of $\sim 0.8 \mathrm{~d}^{-1}$ in the $\mathrm{pH}$ range of 6.6 to 8.5 (Tukey's test, $\mathrm{p}<$ 0.05). Below a pH of 6.6, the growth rate of T. amphiox- eia was reduced and was $0.4 \mathrm{~d}^{-1}$ at $\mathrm{pH}$ 6.4, which was significantly different from maximum growth rates (Tukey's test, $\mathrm{p}<0.05$; Fig. $4 \mathrm{~b}$ ).

\section{Growth rate, cell size, and production rate of six common phytoplankton species at lowered pH}

In Expt 2,6 species of phytoplankton were grown in $4 \mathrm{pH}$ treatments $(\sim 7.0, \sim 7.5, \sim 8.0$, and $\sim 8.5)$. No apparent lag phase was observed in any treatments, and the experimental cultures continued balanced growth immediately after inoculation into the 4 experimental $\mathrm{pH}$ levels (Fig. 5).

Growth rates in all 6 species were similar in all $4 \mathrm{pH}$ treatments (ANOVA, p > 0.05; Fig. 6). Likewise, cell size and production rates were similar in all $4 \mathrm{pH}$ treatments (ANOVA, $p>0$. 05). Thus, no significant effects of lowered $\mathrm{pH}$ and increased free $\mathrm{CO}_{2}$ in the ranges studied here $\left(\sim 7.0\right.$ to 8.5 and 5 to $150 \mu \mathrm{mol} \mathrm{l}^{-1}$, respectively) were found in any of the tested strains on any of the measured parameters (Fig. 6).

\section{DISCUSSION}

\section{Marine phytoplankton growth rates at lowered pH}

Our results show that lowered $\mathrm{pH}$ and corresponding increased free $\mathrm{CO}_{2}$ in the range of average surface ocean levels proposed by the end of this century $(\mathrm{pH}$ 7.8 and free $\mathrm{CO}_{2} \sim 30 \mu \mathrm{mol} \mathrm{l}^{-1}$, Houghton et al. 2001) neither increased nor decreased growth and production rates of the 8 species of phytoplankton tested, representing diatoms, dinoflagellates, cryptophytes, and haptophytes. Not many laboratory studies have focused on lowered $\mathrm{pH}$ and marine phytoplankton growth rates. However, our findings agree well with previously published phytoplankton growth rates obtained in the laboratory at lowered $\mathrm{pH}$ of similar 

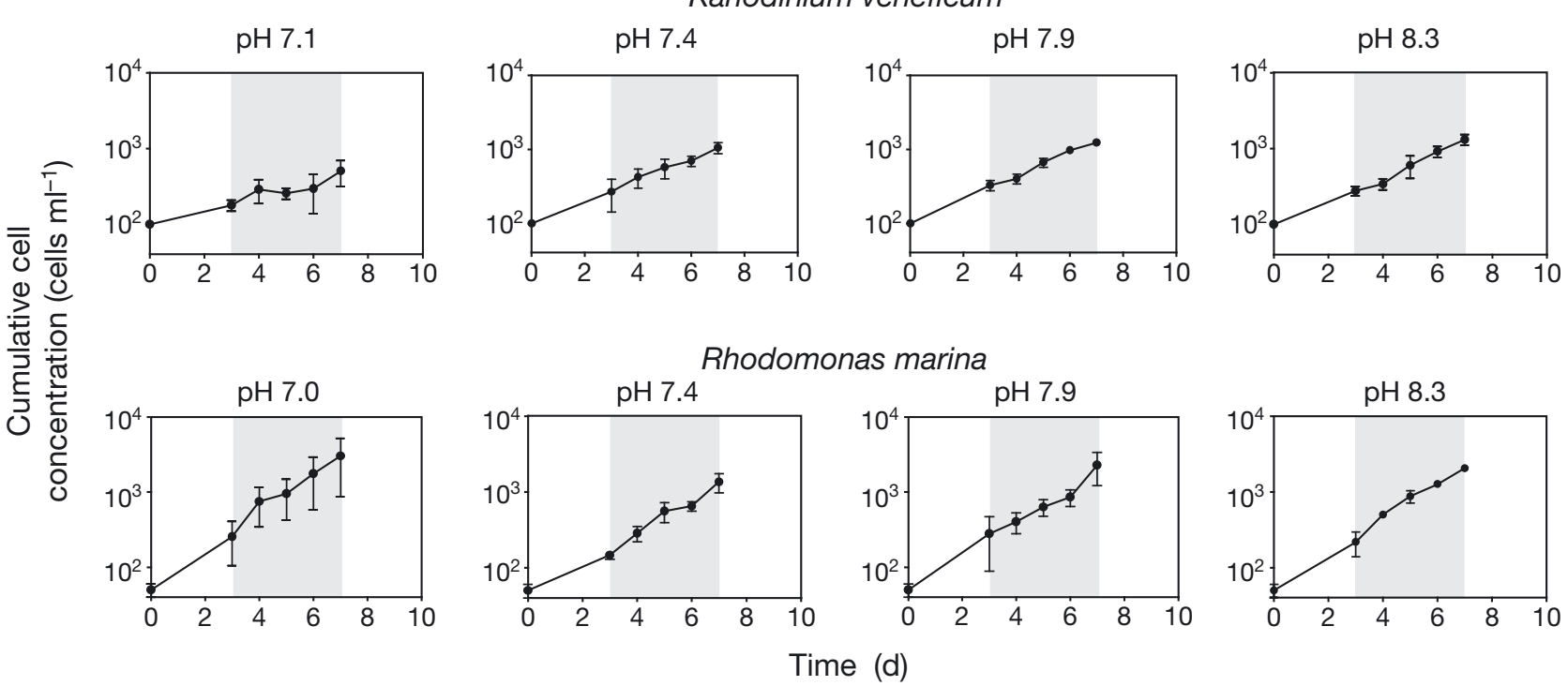

Fig. 5. Karlodinum veneficum and Rhodomonas marina. Expt 2. Effects of lowered pH on growth rates of 6 common phytoplankton species (2 examples are given here). Cumulative cell concentration as a function of time in semi-continuous batch cultures of one slow-growing species (the dinoflagellate $K$. veneficum) and one fast-growing species (the cryptophyte $R$. marina), grown at 4 levels of $\mathrm{pH}$. Data points are means \pm SE $(n=3)$. Shaded areas represent points used in growth rate estimations, while the first $3 \mathrm{~d}$ represent the acclimation period to $\mathrm{pH}$

range ( 7.8-8.5; Table 2, Fig. 7). We collected a substantial part of the published literature on phytoplankton balanced growth rates at lowered $\mathrm{pH}$ and increased free $\mathrm{CO}_{2}$ and found a total of 33 species including 49 strains studied in the $\mathrm{pH}$ range of ocean acidification ( $\mathrm{pH} \sim 7.8$; Table 2). Across this range, reported effects on acclimatized balanced growth rates have only been reported in the calcifying oceanic coccolithophorid Emiliania huxleyi. Concerning the most studied species E. huxleyi (Table 2), there is no clear pattern with regard to effects on its growth rate at lowered $\mathrm{pH} /$ increased $\mathrm{CO}_{2}$, in the range of average ocean acidification ( $\mathrm{pH} \sim 7.8)$. The growth rates of most strains of this ecologically important coccolithophorid are unaffected at $\mathrm{pH}$ 7.8, while a few strains slightly reduce or increase their growth rates (IglesiasRodriguez et al. 2008, Langer et al. 2009, Ridgwell et al. 2009). On the other hand, all other species and strains tested (33 species and 49 strains in total) had similar growth rates at $\mathrm{pH} \sim 7.8$, compared to present day levels $(\mathrm{pH}$ 8.1-8.2). This indicates that marine phytoplankton, in general, are adapted to tolerate the modeled global average surface water drop of $\mathrm{pH}$ due to ocean acidification by the year 2100 ( $\mathrm{pH} \sim 7.8)$. This seems to apply to most major taxonomic groups of phytoplankton (Table 2).

A major concern in ecophysiological experiments on phytoplankton is acclimation, involving cellular regulation and resource allocation of cultures when introduced to a new environment (Brand 1982, Hurd et al. 2009, Barcelos e Ramos et al. 2010). Expression of essential metabolic processes of eukaryotic microorganisms changes with the environment, and before realistic comparisons between treatments can be made, cultures need to stabilize into a new physiological state and achieve balanced growth under the experimental growth conditions. These often differ from the conditions under which the cultures are maintained. Therefore, phytoplankton ecologists often acclimatize their cultures for several generations (often 5 to 10 generations). Previous studies on the effects of lowered $\mathrm{pH}$ and increased free $\mathrm{CO}_{2}$ on phytoplankton growth rates differed considerably with respect to the duration of the acclimation period (Table 2). However, in Emiliania huxleyi, acclimation to increased free $\mathrm{CO}_{2}$ and lowered $\mathrm{pH}$ has recently been shown to occur within hours (Barcelos e Ramos et al. 2010). The generality of these findings is limited by only 1 other report, where no differences were found between photosynthetic response after 1 and $5 \mathrm{~h}$ of acclimation of 2 species of phytoplankton (Chen \& Durbin 1994). In our study, after a sudden drop of $\mathrm{pH}$ by 1 unit $\mathrm{d}^{-1}$, the cultures did not show any sign of a lag phase, but continued balanced growth immediately. This adds 8 species to the list of species able to respond and acclimatize quickly to $\mathrm{pH}$ and $\mathrm{CO}_{2}$ changes, which has large implications for literature comparisons across different acclimation periods and may simplify interpretations of studies with natural incubations (shipborne and mesocosm studies). 
Spatial variation in the magnitude of ocean acidification will occur, affecting some areas more than others (McNeil \& Matear 2008). Full strength oceanic seawater contains high $\mathrm{TCO}_{2}$ concentrations ( 2.2 to $\left.2.4 \mathrm{mM}\right)$ which act to buffer $\mathrm{pH}$ changes. However, in coastal waters with a generally lower content of $\mathrm{TCO}_{2}$, $\mathrm{pH}$ fluctuates considerably more in time and space (Hansen 2002, Middelboe \& Hansen 2007, Wootton et al. 2008). In coastal surface waters, $\mathrm{pH}$ fluctuations

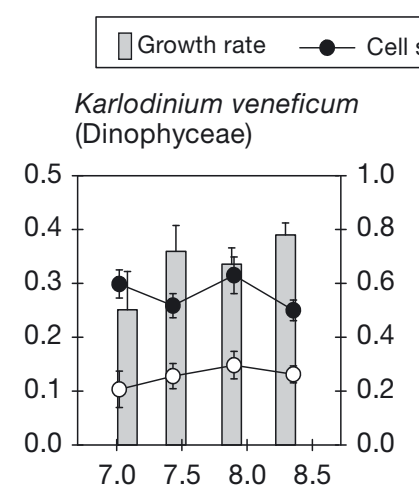

Prorocentrum micans (Dinophyceae)

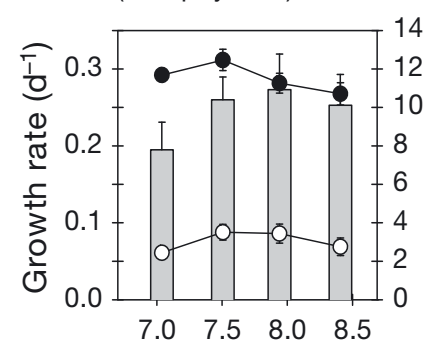

Coscinodiscus granii (Bacillariophyceae)

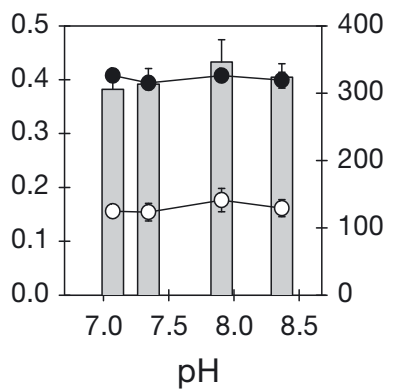

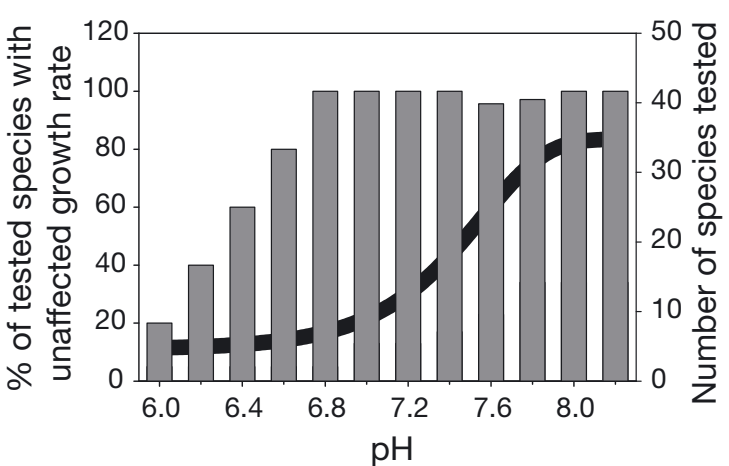

Fig. 7. Percentage of phytoplankton species tested as a function of $\mathrm{pH}$, in which acclimated balanced growth rates are unaffected, compared to maximum growth rates (grey bars). Affected growth rates were defined as a $>20 \%$ reduction of maximum growth rates. The black line represents the number of species tested as a function of pH. Fig. 7 is based on Table 2

from 7.5 to 9 at daily and seasonal time scales are common (Hinga 1992, 2002, Hansen 2002, Middelboe \& Hansen 2007, Wootton et al. 2008). Therefore, it is necessary to consider even larger ranges of lowered $\mathrm{pH}$ and increased $\mathrm{CO}_{2}$, when evaluating potential effects of ocean acidification on phytoplankton growth rates. If we widen the lowered $\mathrm{pH}$ range to include these natural fluctuations ( $\mathrm{pH} 7.5$ to 9.0), the number of literature reports on phytoplankton growth rates decreases markedly. Nevertheless, all of the 23 species tested thus far down to a $\mathrm{pH}$ of 7.5 , including the 8 species tested here, maintained their maximum growth rates (Table 2, Fig. 7). Natural variations in $\mathrm{pH}$ occur at several scales in environments where phytoplankton photosynthesis takes place. In general, pH decreases as a function of water column depth, and bottom layer water with $\mathrm{pH}$ close to 7.0 has been reported from nature (Byrne et al. 2010). In a survey of pH in Monterey Bay, California (USA), $\mathrm{pH}$ generally ranged from 7.6 at $500 \mathrm{~m}$ depth to 8.2 at the surface (Byrne et al. 2010). On the continental shelf of western North America, Feely et al. (2008) reported upwelling of corrosive bottom water of $\mathrm{pH} 7.6 \mathrm{up}$ to a depth of $50 \mathrm{~m}$. In estuaries, $\mathrm{pH}$ varies at small spatial scales, often resulting in environmental gradients (Hinga 2002). Alkalinity and $\mathrm{TCO}_{2}$ concentration in river water vary considerably depending on the geology of the catchment areas. In estuaries with relatively low $\mathrm{TCO}_{2}$ levels, $\mathrm{pH}$ measurements below 7.5 are common, and even $\mathrm{pH}$ values as low as 6.5 have been observed in nature (Hinga 2002). On even smaller spatial and temporal scales, rainfall (which often has a $\mathrm{pH}$ of $\sim 5$ ), may also affect the $\mathrm{pH}$ environment of phytoplankton (Bates \& Peters 2007).

Future ocean acidification may affect all of these natural $\mathrm{pH}$ extremes, indicating that even $\mathrm{pH}$ levels $<7.5$
Fig. 6. Expt 2. Effects of lowered pH on common species of coastal marine phytoplankton. Growth rates $\left(\mathrm{d}^{-1}\right)$, cell volume $\left(\mu \mathrm{m}^{3}\right)$, and production rates $\left(\mu \mathrm{m}^{3} \mathrm{cell}^{-1} \mathrm{~d}^{-1}\right)$ of 6 species grown at 4 different $\mathrm{pH}$ levels. The cultures were grown under nutrient and light replete conditions for $1 \mathrm{wk}$ and acclimation to $\mathrm{pH}$ during a period of $3 \mathrm{~d}$ where $\mathrm{pH}$ was kept constant. No significant differences between growth rates, cell volume, and production rates under the different $\mathrm{pH}$ treatments were observed in any of the tested species $(p>0.05)$. Data points are means \pm SE $(n=3)$ 
Table 2. (continued overleaf) Marine phytoplankton groups, species, and strains studied in the laboratory for effects of lowered $\mathrm{pH} /$ increased $\mathrm{CO}_{2}$ on balanced acclimatized growth rates. The $\mathrm{pH}$ range for maximum exponential growth rate is defined as the $\mathrm{pH}$ over which growth rates were at their maximum levels and varied $<20 \%$; lower $\mathrm{pH}$ at which exponential growth is affected is defined as the $\mathrm{pH}$ at which a $>25 \%$ reduction of growth rate compared to maximum growth rate occurred; and the lower $\mathrm{pH}$ limit for growth was defined as the $\mathrm{pH}$ at which growth $=0.0 \mathrm{~d}^{-1}$. Only studies using replicated acclimatized growth rates obtained over at least $3 \mathrm{~d}$ are included. nd: not determined; na: information not available

\begin{tabular}{|c|c|c|c|c|c|}
\hline $\begin{array}{l}\text { Phytoplankton group } \\
\text { Species } \\
\text { Strain ID }\end{array}$ & $\begin{array}{l}\text { pH range for } \\
\text { max. exponential } \\
\text { growth rate }\end{array}$ & $\begin{array}{c}\text { Lower pH at } \\
\text { which exponential } \\
\text { growth is affected }\end{array}$ & $\begin{array}{l}\text { Lower } \mathrm{pH} \\
\text { limit for } \\
\text { growth }\end{array}$ & $\begin{array}{l}\text { Duration of } \\
\text { acclimation } \\
\text { period to } \mathrm{pH}\end{array}$ & Source \\
\hline \multicolumn{6}{|l|}{ Dinoflagellates } \\
\hline \multicolumn{6}{|l|}{ Prorocentrum minimum } \\
\hline K-0295 & $7.3-8.9$ & nd, but $<7.3$ & nd & $2 \mathrm{~d}$ & Hansen (2002) \\
\hline $\mathrm{K}-1138$ & $7.0-8.4$ & nd, but $<7.0$ & nd & $3 \mathrm{~d}$ & Present study \\
\hline \multicolumn{6}{|l|}{ Prorocentrum micans } \\
\hline $\mathrm{K}-1137$ & $7.0-8.4$ & nd, but $<7.0$ & nd & $3 \mathrm{~d}$ & Present study \\
\hline PML 97 & $7.5-8.8$ & nd, but $<7.5$ & nd & $2 \mathrm{~d}$ & Kain \& Fogg (1960) \\
\hline \multicolumn{6}{|l|}{ Heterocapsa triquetra } \\
\hline K-0481 & $7.6-9.1$ & nd, but $<7.6$ & nd & $2 \mathrm{~d}$ & Hansen (2002) \\
\hline na & $6.7-8.6$ & 6.6 & 5.9 & $4 \mathrm{~d}$ & Present study \\
\hline \multicolumn{5}{|l|}{ Ceratium lineatum } & Hansen (2002) \\
\hline $\begin{array}{l}\text { Ceratium fusus } \\
\text { na }\end{array}$ & $7.35-8.2$ & nd, but $<7.35$ & nd & $<2 d$ & Søderberg \& Hansen (2007) \\
\hline \multicolumn{6}{|l|}{ Ceratium furca } \\
\hline \multicolumn{6}{|l|}{ Ceratium tripos } \\
\hline \multicolumn{6}{|l|}{ Karlodinium veneficum } \\
\hline \multicolumn{6}{|l|}{ Scrippsiella trocoideae } \\
\hline na & $7.8-9.2$ & nd, but $<7.8$ & nd & 9 generations & Burkhardt et al. (1999) \\
\hline \multicolumn{6}{|l|}{ Alexandrium minutum } \\
\hline \multicolumn{6}{|l|}{ Diatoms } \\
\hline \multicolumn{6}{|c|}{ Thallasiosira pseudonana } \\
\hline $3 \mathrm{H}$ & $7.1-8.9$ & nd, but $<7.1$ & nd & $<1 \mathrm{~d}$ & Chen \& Durbin (1994) \\
\hline \multicolumn{6}{|l|}{ Thallasiosira weissflogii } \\
\hline \multicolumn{6}{|l|}{ Thallasiosira oceanica } \\
\hline $\begin{array}{l}\text { Thallasiosira punctige } \\
\text { na } \\
\text { na }\end{array}$ & $\begin{array}{l}7.8-9.1 \\
7.5-8.5\end{array}$ & $\begin{array}{l}\text { nd, but }<7.8 \\
\text { nd, but }<7.5\end{array}$ & $\begin{array}{l}\text { nd } \\
\text { nd }\end{array}$ & $\begin{array}{l}9 \text { generations } \\
\text { na }\end{array}$ & $\begin{array}{l}\text { Burkhardt et al. (1999) } \\
\text { Riebesell et al. (1993) }\end{array}$ \\
\hline $\begin{array}{l}\text { Ditulum brightwelli } \\
\text { na }\end{array}$ & $7.7-8.5$ & nd, but $<7.7$ & nd & na & Riebesell et al. (1993) \\
\hline \multicolumn{5}{|l|}{ Rizosolenia $c f$. alata } & Riebesell et al. (1993) \\
\hline \multicolumn{6}{|c|}{ Phaeodactylum tricornutum } \\
\hline CCAP $1052 / 1 \mathrm{~A}$ & $7.8-9.1$ & nd, but $<7.8$ & nd & 9 generations & Burkhardt et al. (1999) \\
\hline CCAP 1052/1A & $7.3-8.9$ & nd, but $<7.3$ & nd & na & Johnston (1996) \\
\hline CCMP 630 & $7.7-8.5$ & nd, but $<7.7$ & nd & 7 generations & Shi et al. (2010) \\
\hline $\begin{array}{l}\text { Skeletonema costatum } \\
\text { na }\end{array}$ & $6.5-8.5$ & nd, but $<6.5$ & nd & $3 d$ & Taraldsvik \& Myklestad (2000) \\
\hline $\begin{array}{l}\text { Coscinodiscus granii } \\
\text { K-1048 }\end{array}$ & $7.1-8.4$ & nd but $<7.1$ & nd & $3 d$ & Present study \\
\hline $\begin{array}{l}\text { Coscinodiscus wailesi } \\
\text { na }\end{array}$ & $7.8-8.6$ & nd, but $<7.8$ & nd & 9 generations & Burkhardt et al. (1999) \\
\hline
\end{tabular}


Table 2 (continued)

\begin{tabular}{|c|c|c|c|c|c|}
\hline $\begin{array}{l}\text { Phytoplankton group } \\
\text { Species } \\
\text { Strain ID }\end{array}$ & $\begin{array}{l}\text { pH range for } \\
\text { max. exponential } \\
\text { growth rate }\end{array}$ & $\begin{array}{c}\text { Lower pH at } \\
\text { which exponential } \\
\text { growth is affected }\end{array}$ & $\begin{array}{l}\text { Lower pH } \\
\text { limit for } \\
\text { growth }\end{array}$ & $\begin{array}{l}\text { Duration of } \\
\text { acclimation } \\
\text { period to } \mathrm{pH}\end{array}$ & Source \\
\hline \multicolumn{6}{|l|}{ Diatoms (continued) } \\
\hline \multicolumn{5}{|l|}{ Asterionella glacialis } & Burkhardt et al. (1999) \\
\hline $\begin{array}{l}\text { Asterionella japonica } \\
\text { na }\end{array}$ & $7.5-8.5$ & nd, but below 7.5 & nd & $2 d$ & Kain \& Fogg (1958a) \\
\hline \multicolumn{6}{|l|}{ Coccolithophorids } \\
\hline \multicolumn{6}{|l|}{ Emiliania huxleyi } \\
\hline PML B92/11 & $7.8-8.6$ & nd, but $<7.8$ & nd & Unclear & Rost et al. (2002) \\
\hline PML 92A & $7.46-8.30$ & nd, but $<7.46$ & nd & 7 and $14 \mathrm{~d}$ & Leonardos \& Geider (2005) \\
\hline RCC1256 & $7.81-8.56$ & 7.81 & nd & 12 generations & Langer et al. (2009) \\
\hline RCC1238 & $7.71-8.56$ & nd, but $<7.71$ & nd & 12 generations & Langer et al. (2009) \\
\hline RCC1216 & $7.71-8.56$ & nd, but $<7.71$ & nd & 12 generations & Langer et al. (2009) \\
\hline RCC1212 & $7.71-8.56$ & nd, but $<7.71$ & nd & 12 generations & Langer et al. (2009) \\
\hline CCMP371 & $7.9-8.1$ & nd, but $<7.9$ & nd & 7 generations & Feng et al. (2008) \\
\hline NZEH(COWPO6) & $7.85-8.1$ & 7.77 & nd & 9 generations & Iglesias-Rodriguez et al. (2008) \\
\hline CCMP 374 & $7.8-8.5$ & nd, but $<7.85$ & nd & 7 generations & Shi et al. (2010) \\
\hline CCAP 920/2 & $7.0-8.3$ & nd, but $<7.0$ & nd & na & Johnston (1996) \\
\hline PML 92 & $8.0-8.5$ & 7.8 & nd & na & Johnston (1996) \\
\hline \multicolumn{6}{|l|}{ Coccolithus leptoporus } \\
\hline AC365 & $7.86-8.44$ & nd, but $<7.86$ & nd & 10 generations & Langer et al. (2006) \\
\hline \multicolumn{6}{|l|}{ Coccolithus pelagicus } \\
\hline $\mathrm{AC} 400$ & $7.81-8.56$ & nd, but $<7.81$ & nd & 10 generations & Langer et al. (2006) \\
\hline \multicolumn{6}{|l|}{ Prymnesiophytes } \\
\hline \multicolumn{5}{|l|}{ Isochrysis galbana } & Kain \& Fogg (1958b) \\
\hline \multicolumn{6}{|l|}{ Prymnesium parvum } \\
\hline K-0623 & $7.1-8.4$ & nd, but $<7.1$ & nd & $3 \mathrm{~d}$ & Present study \\
\hline \multicolumn{6}{|l|}{ Cricosphaera elongata } \\
\hline Miliport strain 62 & $7.1-7.8$ & 6.4 & nd & $<14 \mathrm{~d}$ & Swift \& Taylor (1966) \\
\hline \multicolumn{6}{|l|}{ Cryptophytes } \\
\hline \multicolumn{6}{|l|}{ Teleaulax amphioxeia } \\
\hline \multicolumn{6}{|l|}{ Rhodomonas marina } \\
\hline \multicolumn{6}{|l|}{ Cyanobacteria } \\
\hline $\begin{array}{l}\text { Procholorococcus sp. } \\
\text { CCMP1986 }\end{array}$ & $7.8-8.2$ & nd, but $<7.8$ & nd & $14 \mathrm{~d}$ & Fu et al. (2007) \\
\hline Synecococcus sp. & & & & & \\
\hline CCMP1334 & $7.8-8.2$ & nd, but $<7.8$ & nd & $14 \mathrm{~d}$ & Fu et al. (2007) \\
\hline Trichodesmium sp. & & & & & \\
\hline IMS101 & $7.8-8.2$ & nd, but $<7.8$ & nd & $60 \mathrm{~d}$ & Barcelos e Ramos et al. (2007) \\
\hline
\end{tabular}

may be common in an acidified ocean. Apart from our study, only a few laboratory studies of marine phytoplankton growth rates have used seawater $\mathrm{pH}$ at such extreme levels (Swift \& Taylor 1966, Chen \& Durbin 1994, Johnston 1996, Hwang \& Lu 2000, Taraldsvik \& Myklestad 2000, Hansen 2002, Søderberg \& Hansen 2007). Overall, these previous studies all reported a very high tolerance to lowered $\mathrm{pH}$ (Table 2, Fig. 7). The growth rate of the brackish water calcifying coccolithophorid Cricosphaera elongata at pH 7.0 was not significantly reduced compared to maximum growth rates in the $\mathrm{pH}$ range of 7.8 to 8.6 (Swift \& Taylor 1966), and growth rates of the coastal diatom Skeletonema costatum remained constant ( 2.4 divisions $\mathrm{d}^{-1}$ ) from $\mathrm{pH}$ of 6.5 to 8.5 (Taraldsvik \& Myklestad 2000). Chen \& Durbin (1994) investigated the growth rates of one oceanic and one coastal species of diatom (viz. Thallasiosira oceanica and T. pseudonana) under a $\mathrm{pH}$ range of 7.0 to 9.5 and found no reduction of growth rates of both species at the lowest $\mathrm{pH}$ tested $(\mathrm{pH} 7.0)$. In our study, growth rates of the dinoflagellate Heterocapsa triquetra were not significantly reduced until $\mathrm{pH}$ was 
lowered to 6.5 , while the growth rates of the cryptophyte Teleaulax amphioxeia were unaffected by lowered $\mathrm{pH}$ down to $\sim 6.1$. The dinoflagellates Karlodinum veneficum, Prorocentrum minimum, and P. micans, the cryptophyte Rhodomonas marina, the diatom Coscinodiscus granii, and the haptophyte Prymnesium parvum all maintained maximum growth and production rates down to a $\mathrm{pH}$ of $\sim 7.0$. In summary, the unaffected growth rates of 17 species tested so far at $\mathrm{pH}$ levels $<7.5$ indicate that phytoplankton growth rates in general are tolerant of the ecologically relevant changes in $\mathrm{pH}$ and free $\mathrm{CO}_{2}$ (Table 2, Fig. 7). We speculate that adaptation of phytoplankton to the range of present and past $\mathrm{pH}$ fluctuations in the ocean (Pearson \& Palmer 2000, Hansen 2002, Hinga 2002, Ridgwell \& Schmidt 2010), can explain the wide tolerance of these organisms to lowered $\mathrm{pH}$ levels. However, most of the species tested at lowered $\mathrm{pH}(<7.5)$ represent coastal species, and truly oceanic species are likely to be adapted to a smaller range of $\mathrm{pH}$, and are therefore likely to be more sensitive to $\mathrm{pH}$ changes. Only one oceanic species, the diatom T. oceanica, has been tested at $\mathrm{pH}<7.5$, and this species was able to grow unaffected down to $\mathrm{pH} 7.0$ (Chen \& Durbin 1994). More data on the tolerance to lowered $\mathrm{pH}$ of growth rates of oceanic species are needed to evaluate a potential difference between oceanic and coastal phytoplankton.

\section{Lower pH tolerance limit for marine phytoplankton growth}

Here we report the absolute lower $\mathrm{pH}$ tolerance limits for positive growth rates of the first 2 tested marine phytoplankton species at $\mathrm{pH}$ levels of $\sim 6.0$. At the high range of $\mathrm{pH}$, tolerance limits for growth of marine phytoplankton are well studied, and is in general around 9, but with large species-specific variation (Hansen 2002). At high levels of $\mathrm{pH}$, a larger fraction of $\mathrm{TCO}_{2}$ is present as $\mathrm{CO}_{3}{ }^{2-}$, which is unavailable for phytoplankton photosynthesis, and it has been discussed whether growth at high $\mathrm{pH}$ is mainly reduced by $\mathrm{TCO}_{2}$ limitation or by direct pH effects (Hansen et al. 2007). However, several studies on this controversy between $\mathrm{TCO}_{2}$ and $\mathrm{pH}$ limitations have clearly indicated that limitation is due to direct $\mathrm{pH}$ effects, and very low levels of $\mathrm{TCO}_{2}$ are required to limit growth rates (<0.5 mM; Hansen et al. 2007, Søderberg \& Hansen 2007). At lowered $\mathrm{pH}$, despite the fact that $\mathrm{TCO}_{2}$ content in our medium was reduced compared to higher $\mathrm{pH}$ levels $(\sim 0.8 \mathrm{mM}$ at $\mathrm{pH} 6$ and $\sim 1.4 \mathrm{mM}$ at $\mathrm{pH}$ 7 , due to water/air contact during preparation), most $\mathrm{TCO}_{2}$ was present as available $\mathrm{CO}_{2}$ and $\mathrm{HCO}_{3}^{-}$. Therefore, it is very likely that the reduced growth rates observed (close to their lower limits for growth) for the 2 species Heterocapsa triquetra and Teleualax ampohioxeia were not due to $\mathrm{TCO}_{2}$ limitation, but to direct $\mathrm{pH}$ effects. The most probable direct effect may be an inability to maintain a favorable intracellular $\mathrm{pH}$. Our results indicate that marine phytoplankton are well adapted to do so, even at very low $\mathrm{pH}$ levels by marine standards. Insensitivity of phytoplankton growth rates to even lower $\mathrm{pH}$ has been reported. The marine dinoflagellate Alexandrium minutum is able to grow at maximum rates even down to $\mathrm{pH} 5.5$ (Hwang \& Lu 2000). Regulation of intracellular $\mathrm{pH}$ in phytoplankton has only been studied in freshwater species. Some of these are able to maintain a constant intracellular $\mathrm{pH}$ of 7.0 , across an extracellular $\mathrm{pH}$ range of 3.0 to 8.0 (Lane \& Burris 1981). The freshwater cryptophyte Cryptomonas sp., which is closely related to Rhodomonas marina investigated in the present study, tolerated wide $\mathrm{pH}$ fluctuations from $\mathrm{pH} 4.4$ to 9.65 and was able to regulate its cell volume over this range (Weisse \& Stadler 2006). Some common freshwater species of the green algal genus Chlamydomonas show positive growth rates over more than $7 \mathrm{pH}$ units and keep their intracellular $\mathrm{pH}$ constant over this range (Spijkerman 2005, Gerloff-Elias et al. 2006). In addition to affecting intracellular $\mathrm{pH}$, low extracellular $\mathrm{pH}$ may directly affect membrane potential, energy partitioning, and enzyme activity (Beardall \& Raven 2004, Riebesell 2004, Giordano et al. 2005). Considering the ongoing ocean acidification, the absolute lower limits for growth and intracellular $\mathrm{pH}$ regulation of marine phytoplankton need more attention.

Acknowledgements. We are indebted to Gert Hansen at the Scandinavian Culture Collection of Algae and Protozoa for providing cultures for this investigation. We also thank Lasse Tor Nielsen and 2 anonymous referees for comments and suggestions which greatly improved the manuscript. T.B. was funded by a PhD grant provided by the Faculty of Science, University of Copenhagen. This study was also supported by the Danish Research Council to P.J.H., grant no 272-06-0485.

\section{LITERATURE CITED}

Barcelos e Ramos J, Biswas H, Schulz KG, LaRoche J, Riebesell U (2007) Effect of rising atmospheric carbon dioxide on the marine nitrogen fixer Trichodesmium. Global Biogeochem Cycles 21:GB2028

Barcelos e Ramos J, Muller MN, Riebesell U (2010) Shortterm response of the coccolithophore Emiliania huxleyi to an abrupt change in seawater carbon dioxide concentrations. Biogeosciences 7:177-186

Bates NR, Peters AJ (2007) The contribution of atmospheric acid deposition to ocean acidification in the subtropical North Atlantic Ocean. Mar Chem 107:547-558

Beardall J, Raven JA (2004) The potential effects of global climate change on microalgal photosynthesis, growth and ecology. Phycologia 43:26-40 
Brand LE (1982) Genetic-variability and spatial patterns of genetic differentiation in reproductive rates of the marine coccolithophores Emiliania huxleyi and Geophyrocapsa oceanica. Limnol Oceanogr 27:236-245

Brewer PG (1997) Ocean chemistry of the fossil fuel $\mathrm{CO}_{2}$ signal: the haline signal of 'business as usual'. Geophys Res Lett 24:1367-1369 doi:10.1029/97GL01179

Burkhardt S, Riebesell U, Zondervan I (1999) Effects of growth rate, $\mathrm{CO}_{2}$ concentration, and cell size on the stable carbon isotope fractionation in marine phytoplankton. Geochim Cosmochim Acta 63:3729-3741

Burkhardt S, Amoroso G, Riebesell U, Sultemeyer D (2001) $\mathrm{CO}_{2}$ and $\mathrm{HCO}_{3}^{-}$uptake in marine diatoms acclimated to different $\mathrm{CO}_{2}$ concentrations. Limnol Oceanogr 46: 1378-1391

Byrne RH, Mecking S, Feely RA, Liu XW (2010) Direct observations of basin-wide acidification of the North Pacific Ocean. Geophys Res Lett 37:L02601 doi:10.1029/2009 GL040999

> Caldeira K, Wickett ME (2003) Anthropogenic carbon and ocean $\mathrm{pH}$. Nature 425:365

Chen CY, Durbin EG (1994) Effects of pH on the growth and carbon uptake of marine phytoplankton. Mar Ecol Prog Ser 109:83-94

Feely RA, Sabine CL, Hernandez-Ayon JM, Ianson D, Hales B (2008) Evidence for upwelling of corrosive 'acidified' water onto the continental shelf. Science 320:1490-1492

Feng Y, Warner ME, Zhang Y, Sun J, Fu FX, Rose JM, Hutchins DA (2008) Interactive effects of increased $\mathrm{pCO}_{2}$, temperature and irradiance on the marine coccolithophore Emiliania huxleyi (Prymnesiophyceae). Eur J Phycol 43: 87-98

Feng YY, Hare CE, Leblanc K, Rose JM and others (2009) Effects of increased $\mathrm{pCO}_{2}$ and temperature on the North Atlantic spring bloom. I. The phytoplankton community and biogeochemical response. Mar Ecol Prog Ser 388: 13-25

Fu FX, Warner ME, Zhang YH, Feng YY, Hutchins DA (2007) Effects of increased temperature and $\mathrm{CO}_{2}$ on photosynthesis, growth, and elemental ratios in marine Synechococcus and Prochlorococcus (Cyanobacteria). J Phycol 43:485-496

Gerloff-Elias A, Barua D, Mölich A, Spijkerman E (2006) Temperature- and $\mathrm{pH}$-dependent accumulation of heat-shock proteins in the acidophilic green alga Chlamydomonas acidophila. FEMS Microbiol Ecol 56:345-354

> Giordano M, Beardall J, Raven JA (2005) $\mathrm{CO}_{2}$ concentrating mechanisms in algae: mechanisms, environmental modulation, and evolution. Annu Rev Plant Biol 56:99-131

Hansen PJ (2002) Effect of high pH on the growth and survival of marine phytoplankton: implications for species succession. Aquat Microb Ecol 28:279-288

> Hansen PJ, Lundholm N, Rost B (2007) Growth limitation in marine red-tide dinoflagellates: effects of $\mathrm{pH}$ versus inorganic carbon availability. Mar Ecol Prog Ser 334:63-71

> Hinga KR (1992) Co-occurrence of dinoflagellate blooms and high $\mathrm{pH}$ in marine enclosures. Mar Ecol Prog Ser 86: 181-187

Hinga KR (2002) Effects of pH on coastal marine phytoplankton. Mar Ecol Prog Ser 238:281-300

Houghton JT, Ding Y, Griggs DJ, Noguer M, van der Winden PJ, Dai X (eds) (2001) Climate change 2001: the scientific basis. Contribution of Working Group I to the Third Assessment Report of the Intergovernmental Panel on Climate Change. Intergovernmental Panel on Climate Change, Cambridge University Press, Cambridge

> Hurd CL, Hepburn CD, Currie KI, Raven JA, Hunter KA (2009) Testing the effects of ocean acidification on algal metabolism: considerations for experimental designs. J Phycol 45:1236-1251

Hwang DF, Lu YH (2000) Influence of environmental and nutritional factors on growth, toxicity, and toxin profile of dinoflagellate Alexandrium minutum. Toxicon 38: 1491-1503

Iglesias-Rodriguez MD, Halloran PR, Rickaby REM, Hall IR and others (2008) Phytoplankton calcification in a high$\mathrm{CO}_{2}$ world. Science 320:336-340

Johnston AM (1996) The effect of environmental variables on ${ }^{13} \mathrm{C}$ discrimination by two marine phytoplankton. Mar Ecol Prog Ser 132:257-263

Kain JM, Fogg GE (1958a) Studies on the growth of marine phytoplankton. 1. Asterionella japonica Gran. J Mar Biol Assoc UK 37:397-413

Kain JM, Fogg GE (1958b) Studies on the growth of marine phytoplankton. 2. Isochrysis galbana Parke. J Mar Biol Assoc UK 37:781-788

Kain JM, Fogg GE (1960) Studies on the growth of marine phytoplankton. 3. Prorocentrum micans Ehrenberg. J Mar Biol Assoc UK 39:33-50

Kim JM, Lee K, Shin K, Kang JH, Lee HW, Kim M, Jang PG, Jang MC (2006) The effect of seawater $\mathrm{CO}_{2}$ concentration on growth of a natural phytoplankton assemblage in a controlled mesocosm experiment. Limnol Oceanogr 51: 1629-1636

> Lakeman MB, von Dassow P, Cattolico RA (2009) The strain concept in phytoplankton ecology. Harmful Algae 8: $746-758$

- Lane AE, Burris JE (1981) Effects of environmental pH on the internal $\mathrm{pH}$ of Chlorella pyrenoidosa, Scenedesmus quadricauda, and Euglena mutabilis. Plant Physiol 68: $439-442$

Langer G, Geisen M, Baumann KH, Klas J, Riebesell U, Thoms S, Young JR (2006) Species-specific responses of calcifying algae to changing seawater carbonate chemistry. Geochem Geophys Geosyst 7:Q09006

Langer G, Nehrke G, Probert I, Ly J, Ziveri P (2009) Strainspecific responses of Emiliania huxleyi to changing seawater carbonate chemistry. Biogeosciences 6:2637-2646

> Leonardos N, Geider RJ (2005) Elevated atmospheric carbon dioxide increases organic carbon fixation by Emiliania huxleyi (Haptophyta), under nutrient-limited high-light conditions. J Phycol 41:1196-1203

> McNeil BI, Matear RJ (2008) Southern Ocean acidification: a tipping point at 450-ppm atmospheric $\mathrm{CO}_{2}$. Proc Natl Acad Sci USA 105:18860-18864

> Mehrbach $\mathrm{C}$, Culberson $\mathrm{CH}$, Hawley JE, Pytkowicz RM (1973) Measurement of apparent dissociation constants of carbonic acid in seawater at atmospheric pressure. Limnol Oceanogr 18:897-907

> Middelboe AL, Hansen PJ (2007) High pH in shallow-water macroalgal habitats. Mar Ecol Prog Ser 338:107-117

Nielsen LT, Jakobsen HH, Hansen PJ (in press) High resilience of two coastal plankton communities to twentyfirst century seawater acidification: evidence from microcosm studies. Mar Biol Res

Pearson PN, Palmer MR (2000) Atmospheric carbon dioxide concentrations over the past 60 million years. Nature 406: 695-699

> Pedersen MF, Hansen PJ (2003) Effects of high pH on a natural marine planktonic community. Mar Ecol Prog Ser 260: 19-31

> Plath DC, Johnson KS, Pytkowicz RM (1980) The solubility of calcite-probably containing magnesium-in seawater. Mar Chem 10:9-29

Ridgwell A, Schmidt DN (2010) Past constraints on the vulner- 
ability of marine calcifiers to massive carbon dioxide release. Nature Geosci 3:196-200

Ridgwell A, Schmidt DN, Turley C, Brownlee C, Maldonado MT, Tortell P, Young JR (2009) From laboratory manipulations to Earth system models: scaling calcification impacts of ocean acidification. Biogeosciences 6:2611-2623

Riebesell U (2004) Effects of $\mathrm{CO}_{2}$ enrichment on marine phytoplankton. J Oceanogr 60:719-729

Riebesell U, Wolf-Gladrow DA, Smetacek V (1993) Carbondioxide limitation of marine phytoplankton growth rates. Nature 361:249-251

Riebesell U, Zondervan I, Rost B, Tortell PD, Zeebe RE, Morel FMM (2000) Reduced calcification of marine plankton in response to increased atmospheric $\mathrm{CO}_{2}$. Nature 407: 364-367

Riebesell U, Schulz KG, Bellerby RGJ, Botros M and others (2007) Enhanced biological carbon consumption in a high $\mathrm{CO}_{2}$ ocean. Nature 450:545-548

Rost B, Zondervan I, Riebesell U (2002) Light-dependent carbon isotope fractionation in the coccolithophorid Emiliania huxleyi. Limnol Oceanogr 47:120-128

Rost B, Riebesell U, Burkhardt S, Sultemeyer D (2003) Carbon acquisition of bloom-forming marine phytoplankton. Limnol Oceanogr 48:55-67

Schulz KG, Barcelos e Ramos J, Zeebe RE, Riebesell U (2009) $\mathrm{CO}_{2}$ perturbation experiments: similarities and differences between dissolved inorganic carbon and total alkalinity manipulations. Biogeosciences 6:2145-2153

Shi D, Xu Y, Morel FMM (2009) Effects of the $\mathrm{pH} / \mathrm{pCO}_{2}$ con-

Editorial responsibility: Graham Savidge,

Portaferry, UK trol method on medium chemistry and phytoplankton growth. Biogeosciences 6:1199-1207

Shi D, Xu Y, Hopkinson BM, Morel FMM (2010) Effect of ocean acidification on iron availability to marine phytoplankton. Science 327:676-679

Søderberg LM, Hansen PJ (2007) Growth limitation due to high $\mathrm{pH}$ and low inorganic carbon concentrations in temperate species of the dinoflagellate genus Ceratium. Mar Ecol Prog Ser 351:103-112

Spijkerman E (2005) Inorganic carbon acquisition by Chlamydomonas acidophila across a $\mathrm{pH}$ range. Can J Bot 83: 872-878

Swift E, Taylor WR (1966) Effect of $\mathrm{pH}$ on division rate of coccolithophorid Cricosphaera elongata. J Phycol 2:121-125

Taraldsvik M, Myklestad SM (2000) The effect of pH on growth rate, biochemical composition and extracellular carbohydrate production of the marine diatom Skeletonema costatum. Eur J Phycol 35:189-194

Tortell PD, DiTullio GR, Sigman DM, Morel FMM (2002) $\mathrm{CO}_{2}$ effects on taxonomic composition and nutrient utilization in an Equatorial Pacific phytoplankton assemblage. Mar Ecol Prog Ser 236:37-43

> Weisse T, Stadler P (2006) Effect of pH on growth, cell volume and production of freshwater ciliates, and implications for their distribution. Limnol Oceanogr 51:1708-1715

Wootton JT, Pfister CA, Forester JD (2008) Dynamic patterns and ecological impacts of declining ocean $\mathrm{pH}$ in a highresolution multi-year dataset. Proc Natl Acad Sci USA 105: 18848-18853

Submitted: May 7, 2010; Accepted: August 20, 2010 Proofs received from author(s): September 17, 2010 